\title{
Løjt-degnen Hans Mikkelsen som salmedigter og andre iagttagelser over et hånd- skrevet salmehæfte *
}

\author{
Af Urban Schrøder.
}

Den dag i dag er Løjt sogn et rigt fundsted for den, som vil udforske vor landsdels historie - også dens kristelige livs og åndelige rørelsers historie. Ofte lykkes det den opmærksomme samler hos folk på Løjtland at finde skriftlige vidnesbyrd om det stærke kristenliv, der har præget mange løjtingerslægter. Således er det lykkedes forfatteren af de følgende sider at finde frem til et håndskrevet hæfte fra tiden omkring år 1800 indeholdende en række salmer, af hvilke en del synes hidtil ukendte. Hæftet, som er på 64 sider $i$ oktav og indbundet $i$ et stykke grát kardus, er smukt prentet og forsynet med fine pennetegninger af gårdejer Hans Hansen Jespersen på „Iversgård“ i Løjt Skovby ${ }^{1}$ og bærer følgende titel:

\author{
En \\ Samling \\ uf \\ Gudelige Sange \\ sammenskrevet \\ af \\ Hans Jespersen i Skovby \\ som Eiere af denne Bog.
}

Hans Jespersen blev født d. 12. maj 1763 som sun af gårdejer Hans Jespersen og hustru Ellen Nielsdatter Knudsen fra Barsø. 30 år gammel blev han d. 18. oktober 1793 gift med Marie Moos fra Avbæk ved Stollig og har vel samtidigt overtaget sin fædrenegàrd. Og han døde d. 19. januar 1842. Hans Jespersen har været en kristeligt opvakt mand, sandsynligvis præget af den

- Efter forfatterens onske er ortografien i det citerede salmehæfte og de omtalte tryk bevaret, således også inkonsekvenser i brugen af stort og lille begyndelsesbogstav. Red. 
herrnhutiske vækkelse, som kom til Løjt sogn med pastor Christian Bendixen, der var sognepræst fra 1755 til 1781, og af hvem han sikkert er konfirmeret. ${ }^{2}$

I alt fald, et udtryk for, hvad der har boet $i$ hans hjerte, finder vi dette salmehæfte, som han har sammenskrevet - måske i lange vinteraftener i slutningen af 1790 'erne. Det indeholder i alt 12 salmer eller åndelige viser og 3 enkelte vers. Af dette samlede indhold synes det meste at være af hidtil ukendt oprin. delse således, at vi her moder hidtil ukendte frugter af gammelt slesvigsk kristenliv. Og disse salmer og vers fortjener af denne grund et nærmere studium.

Ser vi nu forst på de salmer, som det er lykkedes at finde $i$ andre samlinger, da træffer vi som den ældste den anonyme aftensalme „Ret nu gik solens klarhed hen $O g$ dagens blanke lys har os forladt". 3 Den anføres at kunne synges som Kingos aftensalme „Det mulner mod den mørke Nat"4 og har også Kingo'ske klange. Den er imidlertid ikke et arbejde af denne digter, men findes trykt første gang i Johannes Laverentzens „En $\mathrm{Ny}$ og Fuldkommen Dansk Psalme-Boog/ indeholdendes 1010 Psalmer", København 1709 (Nr. 57, s. 73ff). I denne salmebog, der tryktes i flere senere udgaver, ${ }^{5}$ kan Hans Jespersen have fundet salmen. Men mon ikke han som slesviger snarere har taget den fra den i Flensborg trykte anonyme salmebog "Siælens Himmelsche Jerusalem", der udkom 1717 og forhandledes af Hans Kiesby $i$ Tønder? Her findes salmen nemlig også som nr. 60 med samme antal vers (15 vers) og samme melodiangivelse. ${ }^{6}$ Og det er snarere tænkeligt, at en mand på Løjtland har kendt denne slesvigske salmebog end Laverentzens københavnske.

Den næste salme indenfor denne gruppe begynder med følgende vers:

$$
\begin{aligned}
& \text { Ach! naar skal ieg Ende skue } \\
& \text { Paa min Reyse til mit Hiem } \\
& \text { Og forlade denne Tue? } \\
& \text { Naar vil Dagen bryde frem, } \\
& \text { At ieg maa fulkommen der } \\
& \text { Nyde det, ieg ønsker her? } \\
& \text { Er den Tid snart ikke omme, } \\
& \text { At ieg salig hiem maa komme? }
\end{aligned}
$$

Og den bærer som overskrift ordene: „Brudens Salige Vente paa sin Omskiftelse og Fuldkomne Opløsning. Forestillet Et 
Troende Hierte under den Melodie: Som Hiorten med Tørst belangen“. Disse ord, der i vort hæfte er omhyggeligt prentet over en hel side, har karakter af en selvstændig titel. De er i virkeligheden også titelen på et selvstændigt tryk - her blot gengivet i lidt fordrejet form. Thi vi har her for os en tro afskrift af Iaderslev-bogtrykkeren Hinrich Luckanders lille 8 siders hæfte „Brudens Længselsfulde Kom. Forestillende et troende Hiertes Salige Vente paa sin Omskiftelse og fuldkommene Opløsning. Under den Melodie: Som Hiorten med Torst befangen“ fra 1768. Detle nu sjældne Haderslev-tryk, som findes i den på Als fødte pastor Christian Knudsens samlebind „Gudelige Viser og Psalmer trykte i Haderslev",? har Hans Jespersen altså ejet eller kendt. Og vi har her et vidnesbyrd om udbredelsen af de mange tryk, der udgik fra Haderslev bys første bogtrykkeri - også på Løjtland har de været kendte og yndede. ${ }^{8}$

Mens vi er ved denne salme, er det på sin plads at give nogle prøver på dens art og indhold, da den heri ligner en væsentlig del af vort hæftes øvrige numre. Det er Kirkens gamle katolske brudemystik med sin fjerneste kilde i Salomos Højsang i Del gamle Testamente, der karakteriserer den. Denne mystik døde a]drig ud på luthersk grund, men førtes af mænd som f. eks. tyskerne Johann Arndt og Ahasverus Fritsch videre op gennem del 17. århundrede og toges $i$ det følgende århundrede op som væsentlige bestanddele af pietismen og ikke mindst af herrnhutismen. Dens anliggende: at udtrykke kristenlivets inderste erfaring som et kærlighedsforhold, et levende personsforhold mellem Kristus og den kristne til fuldstændig forening mellem de to, mærkes også tydeligt i vor salme. Kristus kaldes her „du min Brudgom“. Og sjælen er „din Brud“, „din træte Due“, som vil "forklaret dig omfavne“ og "dig ret fuldkommen nyde“. Dette er alt livs mål for den kristne, som dig har saa hiertekar, Skiønt jeg ey - og her møder vi noget karakteristisk - kan elske her Saa fuldkommen, som jeg vilde, Dig, ald Salighedens Kildex. Kærligheden til Frelseren når ikke at blive fuldkommen her. Dette opleves først $\mathrm{i}$ det hinsidige blandt de „himmeltagne Slegter“. Derfor lever sjælen her $i$ stadig længsel efter det kommende og glæder sig over, at $»$ Tiden nærmer sig, At ieg med dig holde skal BryllupsFest i Himlens Sal o og staae Brud hos .JESU Side «. Indtil da 
gælder det at bie tålmodigt. Men det er en bien i stadig bøn "Kom! min Hiertens Frelser god" — som i glad forventning og vished; thi „ved dit Blod Jeg er dig trolovet bleven Og din Himmel mig forskreven". Alle den klassiske kristne mystiks hovedmomenter er med i dette kristensyn. Og der går fra denne salme linjer helt tilbage til Kirkens skønneste spiritualitet siden oldtid og middelalder. Men hvem har digtet den? Vi ved det ikke mere.

Det ved vi derimod om de to næste salmer i vort hæfte, som nu skal nævnes. Det er morgensalmen „Op I Jesu velsignede Navn, op min Siel af dit leie“ og aftensalmen „Nu er Dagen og arbeidet endt. Det er tid Siel og Legemer søger sin Roe“. Begge disse salmer, som hver har 8 vers, er forfattet af degnen i Glud og Hjarnø sogne ved Horsens fjord Hans Hass. ${ }^{9}$ Og også de er som „Brudens Længselsfulde Kom“ trykt af Luckander i Haderslev under titelen „Tvende til Guds \&re brugelige Psalmer - - Begge synges som den bekiendte Arie: Ak min Siæll Hvi bedrøver du dig etc. Componeret af den, der synger for at love Gud, og skriver sig Hans Hass i Glud“. ${ }^{10}$ Vi har altså her endnu et vidnesbyrd om udbredelsen af de mange gudelige tryk fra Haderslev og deres betydning for fromhedslivet $i$ vor landsdel - Hans Jespersen har i sit hæfte simpelthen afskrevet Hass' to salmer efter Luckanders tryk. Og trykkeriet i Haderslev må allerede i sin første virketid have været kendt viden om og have tilfredsstillet et behov langt op i Jylland, siden en digter helt oppe ved Horsens har ladet det udsende sine arbejder. ${ }^{11}$ Hans Hass' to salmer til at begynde og slutte dagen med synes for øvrigt at have levet længe på Løjtland. Thi så sent som i 1897 er de af bogtrykkeren Theodor Janke $i$ Ảbenrå genoptrykt $i$ et lille hæfte betitlet „Gamle og nye Sange eller aandelige Viser, til Opbyggelse for christne Venner paany udgivne“. Og at disse "christne Venner" har været at finde på Løjtland, sees deraf, at dette hæfte på sit titelblad har et med særlige typer fremhævet „Loit 1897“. Vi møder her en sen, mere indremissionsk rest af den herrnhutiske kreds, hvis første generation vi synes at møde $\mathbf{i}$ Hans Jespersens hæfte. ${ }^{12}$

Den næste bestanddel af dette, som vi - omend med nogen usikkerhed - aner oprindelsen til, er blot et enkelt vers. Omtrent midt $i$ hæftet findes to sider, af hvilke den til venstre viser en 


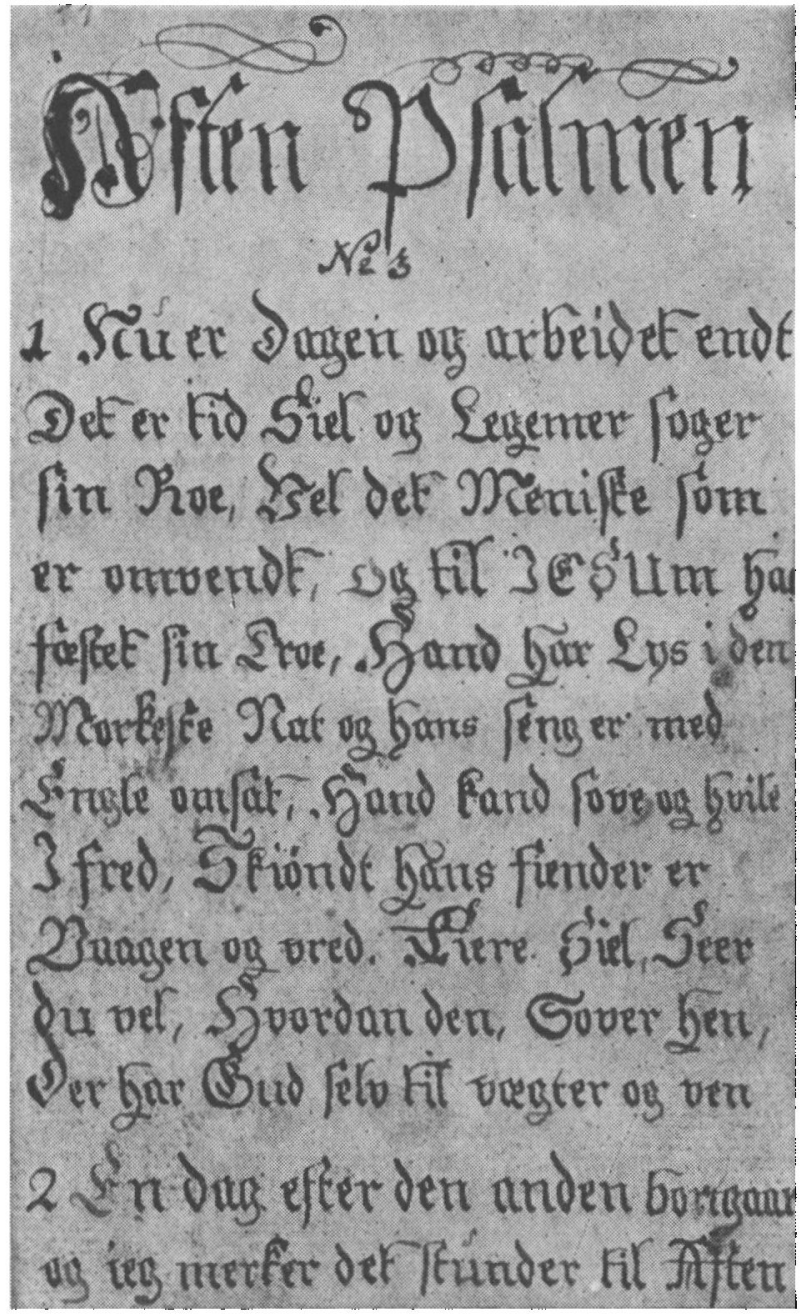

$P a ̊$ denne side $i$ sit hafte har Hans Jespersen afskrevet eller rettere smukt prentet begyndelsen af den jyske degn Hans Hass' aftensalme, som han har kendt, fordi den blev trykt i Luckanders bogtrykkeri $i$ Haderslev. Og dette tryk ma have fundet vej til Lojtland. Lag marke til ordene "- og hans seng er med Engle omsat". De rober, at digteren har kendt den aldgamle og vidtudbredte Engle-bøn om de 14 engle, der holder vagt omkring den sovendes seng - et vidnesbyrd om gammel katolsk fromheds videreleven langt op $i$ nyere tid. 
legning af den Korsfæstede omgivet af bladranker og forsynet med ordene: „Kom JESUM Christum Ihue, som er død og Opstanden for dig, Og lad JESU Guddommelige Lære Bestandig være dig en rettesnor I dit gandske Levnet og Forhold“, mens siden til højre indeni en fint tegnet bladkrans bærer rimet: „Den sang om JESU Blod og Død Er Sielen angenehm og sød“. Og herunder læser vi følgende vers:

Mind, o Jesu, tit mit Hierte
Om dit blod, som for mig flød!
Mind mig om din Qual og Smerte,
Om dit Kors og om din d $\varnothing d !$
Da skal hver min Levestund,
Hvert mit Suk i D $\phi$ dens Blund
Dig, min Frelser, of fret være
Og min D $\varnothing$ d endnu dig ære.

Dette vers minder stærkt om det vers i „Evangelisk-christelig Psalmebog“ fra 1798, som bærer Ove Mallings Navn: „Mind, o Jesu! tidt mit Hierte Om din Trængsel, Qval og Nød“. ${ }^{13} \mathrm{Ja}$, her er så store ligheder, at man fristes til at antage en forbindelse mellem de to vers, f. eks. den, at vort Lajt-vers kunne være en bearbejdelse af Ove Mallings vers. Denne antagelse måtte forudsætte, at „Evangelisk-christelig Psalmebog“ her er forlægget for Hans Jespersens hæfte. Og i så fald måtte dette dateres til efter salmebogens udgivelsesår 1798. Men da det efter hele sit præg ikke kan antages at være skrevet ret mange år efter nævnte årslal, og da en omformning af Mallings vers vel næppe kan have fundet sted $i$ løbet af nogle få år, synes den fremsatte antagelse lidet sandsynlig. Måske tør vi snarere gå den modsatte vej og antage, at vort Løjt-vers er en original slesvigsk frugt af en nu ukendt pen, og at Ove Malling som medlem af den kommission, der udarbejdede „Evangelisk-christelig Psalmebog“, kan have mødt det og omstøbt det i sin egen form. I alt fald må der være en forbindelse mellem de to vers - ellers kan vi ikke forklare de iøjnefaldende ligheder både $i$ sprog og indhold. På den anden side er versene også forskellige. Og lytter vi til den sproglige lone i dem, synes Løjt-verset at repræsentere en ældre tone end Mallings vers - det må være ældst og møder os hos ham i omarbejdet skikkelse. Især sidste halvdel af begge vers taler for denne antagelse. Vi sammenstiller de pågældende linjer: 


\section{Løjt-verset:}

Da skal hver min Levestund, Hvert mit Suk i Dødens Blund, Dig, min Frelser, of fret være Og min Død endnu dig ære!
Mallings vers :

Da mit Liv skal prise dig, Da min Død skal prise dig. Engang du mit St $\varnothing v$ opliver, Og mig Seierskronen giver.

Og det falder $\mathrm{i}$ øjnene, hvordan Mallings vers vidner om en hånd, der har søgt at modernisere de gammeldags klingende udtryk i Løjt-verset „hver min Levestund, Hvert mit Suk i Dødens Blund", har fjernet tanken om offeret til Frelseren og for at undgå den dobbelte omtale af døden indføjet tanken om opstandelsen. Flere ting taler således for, at vort vers er forlægget for Mallings vers. Og der skulle herved fra Hans Jespersens hæfte være faldet nyt lys over en lille enkelthed inden for dansk salmehistorie - omend det må understreges, at vi her stadig står ved en hypotese, der ikke er endeligt bevist, før vi eventuelt finder vort Løjt-vers $i$ en ældre kilde. ${ }^{14}$

Endnu et enkelt vers hører med til de bestanddele af vort hæfte, hvis oprindelse vi kan spore. Det står omhyggeligt prentet sidst i hæftet: „O JESU lad det komme Dog snart dertil engang, At ieg med dine Fromme maae møde dig med Sang - - “. Dette er sidste vers af Brorsons salme "I Jomfruer, I kloge" ${ }^{15}$ Vi bemærker ordene "At ieg med dine Fromme“, der er en afvigelse fra Brorsons egen tekst i "Troens rare Klenodie“ 1739: „At alle dine fromme“ ${ }^{16}$ Men det er sikkert for dristigt herudfra at slutte til en særlig Brorson-tradition.

Vi vender os dernæst til den gruppe på tre salmer og et enkelt vers i Hans Jespersens hæfte, som det slet ikke er lykkedes af finde spor af i nogen anden samling. Den første salme, som har 8 vers og melodiangivelsen: „Komt mit mir in Duncklen Schaten“, begynder således: „Udi vore ungdoms dage Lad os tænke, Gud, paa dig - - - “. Den er en samtale mellem Kristus og sjælen, helt i brudemystikkens tone. Sjælen taler således:

Og Kristus svarer:

Siæle Brudgom, bruden Beiler

At forene sig med dig.

Tag mit Kys, det ikke feiler,

Du igien Jo favner mig.

Jeg har beilet effter dig,

før du beile kunde,

For dig lod ieg døde mig,

Kom, see saar og vunder. 
Salmen er ikke noget poetisk mesterværk, men giver indtryk af at være et privat arbejde af en ukendt, mindre dygtig pen.

Poetisk bedre er derimod den næste ukendte salme, som har 7 vers. Den er en lovprisning af Kristi død og opstandelse og indledes med dette vers:

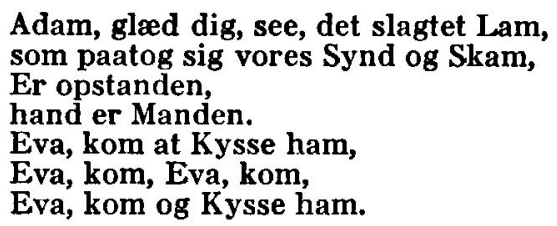

Den tredie salme er atter mindre fejlfri i det poetiske. Den er skrevet til melodien „Nu dagen sig fuldendet har" og udtrykker den tillidsfulde længsel efter den hinsidige herlighed. Og det første af dens 7 vers lyder:

\author{
Er ieg ved Jesu Blod gienkiøbt \\ Fra Synd, fra D $\phi d$, fra Satans Rige, \\ Ved Aand og vand gienf $\varnothing d$ og $D \phi b t$, \\ $O$, Naade, Naade maae ieg sige; \\ Den Naade mig og f $ø$ lge skal \\ Igiennem verdens Ørk og D $\varnothing d s e n s$ Skygges Dal.
}

Med hensyn til, hvem der har digtet disse tre salmer, står vi helt uden holdepunkter. Antageligt er de hjemlige slesvigske arbejder, måske af lokal, løjtingsk oprindelse - i alt fald giver de $i$ indhold og tone udtryk for den herrnhutiske vækkelse, som begyndte på Løjtland i pastor Bendixens tid.

Af helt anden karakter er derimod det enkelte ukendte vers. Det har følgende overskrift: „Tanker ved ædle og velædle $\mathrm{Hr}$. Hans Michelsens grav“ og lyder således:
En vandrings mand kom her til hvile, som med sin Kundskab sig Opsvinget Langt over Stierners blanke top, hand her paa Dydens bane iilte, Hans st $\phi v$ kun Jordens bytte blev.

Hvem forfatteren her er, er det nok også omsonst at gætte på. Han har nok i alt fald ikke hørt til vækkelsens folk, siden han taler om kundskab og dyd, men ikke om Kristi vunder og død. Dog har han antageligt været en løjting. Thi han står "ved Hr. Hans Michelsens grav“. Og vi tager næppe fejl, når vi ved at 


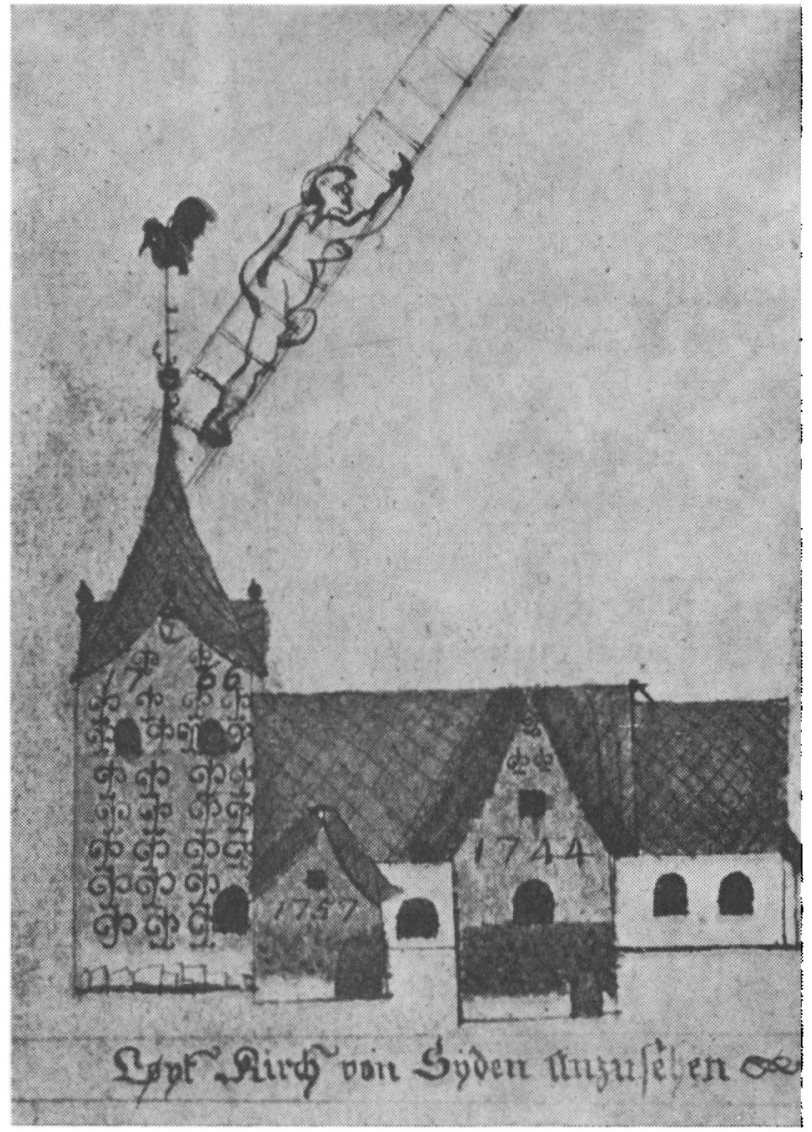

På side $22 i$ sit hafte bringer Hans Jespersen det $i$ teksten omtalte vers "Ved Hans Michelsens grav". $O_{B}$ her ses den folgende side 23: En fin, farvelagt pennetegning af Løjt kirke - vist det aldste kendte billede af denne sarpragede sonderjyske kirke. Skikkelsen, der ad stigen over kirketårnet kravler op til himlen, må betegne Hans Mikkelsen - verset på den foregående side siger jo om ham, at han ,sig Opsvinget Langt over Stierners blanke top".

høre dette navn tænker på den kendte degn i Løjt Hans Mikkelsen, som døde kort før jul 1796. ${ }^{17}$

Og hermed når vi til den sidste gruppe af vort hæftes salmer - nemlig de tre, som her bærer degnens navn, og to andre, der sikkert også er digtet af ham. De er på en måde hele hæftets 
mest interessante del. Thi Hans Mikkelsen er jo ikke just noget kendt navn blandt Slesvigs åndelige digtere. Nok har man vidst, at han har skrevet åndelige sange. ${ }^{18}$ Men det er dog den verdslige, alt andet end åndelige vise, der har bevaret hans navn til vor tid. Det er for viser som „Mærkværdigheder ved Niels Jensen Munkes Er-Øl“, „Den lystige Barselstue“, „Jens Kluses Høstehøjtid“ og "Den onde Birte“,19 han er blevet husket. Det er ham, der har digtet en "Ode ved en Svirebroders Grav" og det næsvise » Regne-Exempel til provst Bargum i Abenrå ${ }^{20}$ og sunget brændevinens pris - „O, herlig Sag, Du Brændeviin, Og dine klare Taarer" - og skrevet gravskriften over sin kollega i landmålerkunsten, som saldrig sveeg, hvor der blev drukken Skaaler ${ }^{2 .}$. Men der har altså også boet et andet sind i denne mand, der ellers var mest kendt som den gennem lange perioder fordrukne degn og højst bramfrie visedigter, der også havde god søgning som $» \operatorname{kog}$ mand . $^{2}$ Har han til tider ført et tvivlsomt levned, så har han også - måske under indflydelse fra sin gejstlige foresatte, pastor Bendixen, og måske $i$ sin modnere alder - haft stunder, da han kunne skrive f. eks. disse linjer: „Naar man for Øje seer som sin forvisset Død, Da Skibets tumlend' Cours til Andagt vistnok presser". ${ }^{23} \mathrm{Og} \mathrm{nu}$ møder vi ham i Hans Jespersens hæfte altså også som salmedigter.

Thi her læser vi på en side følgende: „Herhos et Tillæg af nogle faa Psalmer sammendigtede af Hans Michelsen med hosroyede Melodier“. Og så følger tre salmer, som vi udfra disse ord må tilskrive Hans Mikkelsen. Vi står her vistnok over for et fund, da salmerne synes hidtil at have været ukendte. De skal derfor nu omtales og således fremdrages af deres næsten tohundredårige glemsel.

Alle tre er de passionssalmer og skildrer i stærke vendinger digterens følelser ved betragtningen af Jesu lidelser og død. Den første, som har 12 vers til melodien Af dybsens Nød raaber ieg til dig «, er en opfordring til at følge med til Golgatha og tage plads under Frelserens kors:

Hvo som vil med paa Golgatha,

Han samle sine Tanker,

Saa vil vi der beskue da

Vor Sieles Frelse-Anker.

Vi vil $\mathbf{j}$ Aanden ret besee,

Hvor man, uagtet all Hans Vee,

Ham fast til Korset banker. 
Og nu følger en drastisk skildring af Jesu korsfestelse og død: „Man sprenger, strækker, drager dig, uagtet all din Pines Skrig“. Du, Herre Jesus, hænger der „i tusind Pines Svier“ og vrider dit sårede legeme. „Du flyder $i$ dit Blod - - og alting taalig bier“, indtil du "mod Dødsens Nat Dødfarved nu henblegner“, mens dit Blod "Af Korset, som en stridig Flod, Nedrinder og nedregner". Thi der var ingen anden forløsningsmåde for os syndere. Men her er også nåden: „Den blodig Orm i Korsens Vee Jeg altid vil for Øye see, Hand skal mig nok bevare“. Og Hans Mikkelsen slutter $\mathbf{i}$ tydeligt herrnhutisk tone: "Min Kierlighed! ieg vil igien Med Kierlighed dig møde“.

Den anden salme, som har 16 vers på melodien *Jesu søde Hukommelse ", bærer denne overskrift: "JESU Tørst eller Den paa Korset med Eddikke skenkede Jesus «. Her mediterer digteren, grebet af gru og skam, over den drik, Frelseren fik rakt i sin lidelse:

\section{Hvad var det for en Ledske-Drik. Paa Korsets Træe min JEsus fik? Hvad har man rede til ham først. Nu hand beklager sig af Tørst?}

Det er den sure, stimulerende eddike - dobbelt grusom her, fordi "man ved den sure Saft Forlænge vil hans Levnets Kraft". Er han da glemt i Himmelen? Kommer ikke en engel at styrke ham som i Getsemane? Nej. Og nu følger disse gribende linjer:

Ney! ney! min JEsus bøde maa

For mine Lyster og Attraae:

Hvad som er s $\varnothing d$ for min Natur,

Var $i$ hans Tørst ham Æddik suur.

Naar Vellyst-Drik hos dig faaer Smag,

Da tænk paa den ret grumme Dag,

Paa hvilken i saa suur en Skaal

Din JEsus drak dit Synde-Maal.

Jeg aldrig nyde skal en Taar,

For ieg betænker dine Saar,

Og f $\varnothing \mathrm{r}$ ieg tænker paa den Drik,

Som til Valet min JEsus fik.

Jeg daglig Dags hvert Øyeblik

Betænke vil den suure Drik;

Jeg daglig vil hver Synd af staae;

Nok, naar ieg din kun blive maa.

Og som du tørster efter mig,

Lad mig og Ledskes saa i dig! 
Det er ved læsningen af disse vers næsten uundgåeligt at tænke på Hans Mikkelsens andetsteds bevidnede kærlighed til den „Vellyst-Drik“ brændevinen. Vi kommer ham her så mærkeligt nær og aner, at han måske ligefrem har oplevet en regulær omvendelse og er blevet et medlem af den herrnhutiske kreds, som samledes om pastor Bendixen.

Hans tredie salme, hvis 8 vers kan synges på melodien „O, Menneske! begræd din Synd“, har overskriften „JESU Død“ og begynder således:

O, Jammer, Smerte, Skræk og Vee!
Ak! skal ieg saa min JEsum see
I Smerte allevegne?
Ak, skal ieg see Guds Hierte-Blad
Iblant Misdædere i Rad
Paa Golgatha henblegne?
Ak! skal ieg see den store Mand
I en saa dyb Fornedret-Stand
Og saa elendig Vaade
Paa Korsets Træe i D $\varnothing$ dsens Nat
Henfalme og bortsvime plat?
O, Under overmaade!

Her skildres $i$ voldsomme udtryk og med dyb grebethed selve Jesu Død: „Min Hierte-Frelser, mild og sød“, han, som er ,alles Lives Liv“, bliver kold og stiv. Han, som er selve Guds herlighed, falmer hen i døden. „Hvor maa det giennem Siælen gaae, Hvor Haaret mig om Øret staae" ved synet heraf! Men værst er den selverkendelse, som Frelserens død vækker i digteren:
Ak! ieg var Skyld, min JEsu sød,
I din den haarde skamfuld D $\varnothing \mathrm{d}$ :
Jeg volte dig den Smerte.
Det var min Død, min dom og Band,
Der brød, min kiere Frelsermand,
Dit ret uskyldig Hierte - - -

Derfor beder han om nåde og lover, at „Du altid skal i Siælen staae, Ret som ieg dig for Øye saae I Dødsens sidste Qvale“.

Selv om Hans Mikkelsen i disse tre salmer betjener sig af de inden for Kirkens gamle passionsmystik almindelige begreber og udtryk og således holder sig inden for en traditionel bane, ${ }^{24}$ kan vi dog ikke frakende ham en egen poetisk dygtighed og originalitet: Disse salmer står poetisk over flertallet af hans verdslige 
viser og viser en større omhu i udarbejdelsen, der velsagtens er dikteret af selve deres emner og den helt anden baggrund, som der her skrives udfra.

Endeligt når vi til vort hæftes to sidste salmer, som vi af forskellige grunde mener også at måtte tilskrive Løjt-degnen. Den lørste kaldes på sit særskilte titelblad „Dødens Skue Plads aabned under den bekiendte Melodie: Vor Fader udi Himmerig“ og begynder med disse ord:

En meget ubehagelig
Materie ieg vil for dig,
Mit Menniske, nu sette hid,
Som handler om den sidste Tid,
Naar du af denne Verden maa
Og ind i Evigheden gaae.

Her skildrer $i$ alt 28 vers meget drastisk menneskets endeligt: Den sidste sygdom, da dets legeme er dets "egen Pine-Bænk" dødskampen: „Nu kommer ret den haarde Kamp, Den sidste Fiendes Voldsomhed Udtrykker nu den kaalde Sveed“ - liget, som kendes på, at „Den bleege Farve overalt Afmaler strax en Liig-Gestalt“, og at da „aabner sig i samme Stund Den saa henfaldne døde Mund" - ligstuen med kiste og "Jorde-Blee" og den „ulidelige Stank“, der gør, at „den, som elskdest uden Svig, Omfavnes ey, naar den er Liig“ - og endeligt graven, "Som er bemenget i Gemeen Med Hoved-Pander, Døde-Been“, og „Hvor Orme kryber ind og ud“, så vi kan se de huler, hvor øjnene har siddet, og det, som var næsens sted. Sådant er menneskets endeligt. Og bagved venter evigheden, hvorfor digteren slutteligt spørger: Er du beredt hertil? Står du „i Naadens milde Skin“, så at, når dit lig „maa Sin Raadnelse igiennemgaae, Din Siel i Lyset da maa boe Hos Gud i de Udvaldes Roe?".

Den anden af disse salmer har også sit særskilte titelblad med disse ord: „Overflødighed for Mangel eller En Velsignet Sommer for en trang Vinter forandret efter Guds milde Forsyn under den Mel. Gud Fader udi Himmerig“. Dette er en sommersalme, af hvis 33 vers det første lyder således:

Gak ud omkring i Mark og Eng, opløft Fornuftig $\emptyset y e$, Giv agt paa alting der $i$ Fleng og merk paa dette n $\varnothing y e$. 
Denne og den folgende illustration fra

Hans Jespersens hofte vidner om stor tegnekunst og viser tillige mange lojtingers to hovedbeskaftigelser:

Sofarten og landbruget. Bondesennerne drog vidt over fjerne have - nogle vides ogsa at have deltaget $i$ hvalfangst - og vendte sa hjem for at dyrke fadrenejorden.

Hvalfangerscenen her med dens fine detaljer vidner om selvoplevelse.

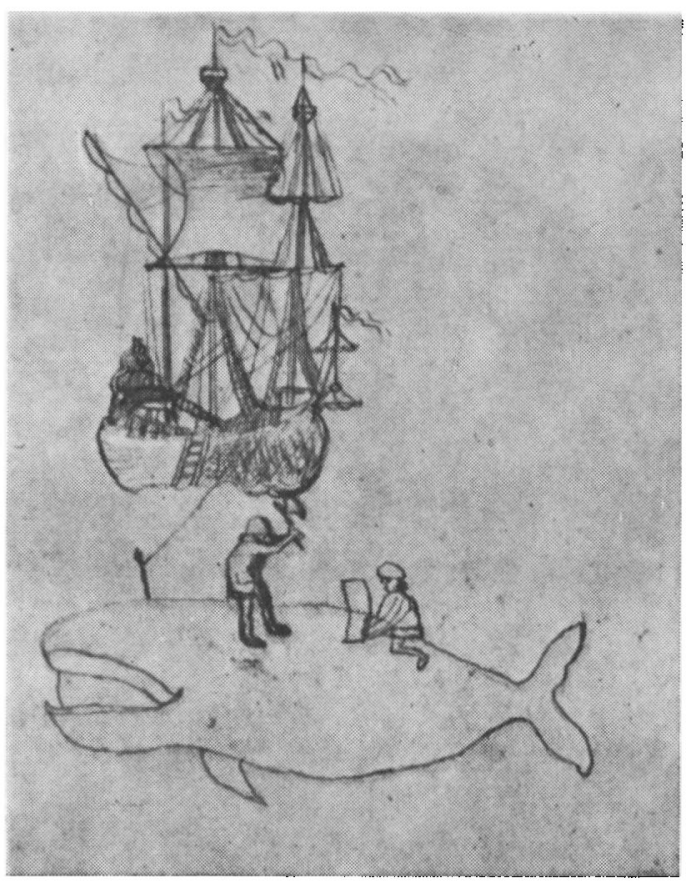

Salmen udmaler med taknemlighed det frydefulde syn af markernes grøde, der må "fyre ret vor Andagt op til Priis og tak og Ere Viit over alle Stiernes top vor store Gud at bære“. Særlig। stærkt taler Løjtlands sommerfrodighed om Guds forsyn over for den fattige, hvem „hine riige Daarer Kort siden $i$ den svare Tid aftrykte Suk og Taarer", idet de nægtede ham korn og brød af deres overflod. Men nu:

See, hvilken s $\varnothing \mathrm{d}$ og venlig Gud:

dig alting var afkortet,

Nu har du fra hans Forsyn bud,

hans haand er uforkortet.

Og ikke blot til sine børn sender Gud sin godheds frugt, men også til de ugudelige:

Sin Soel hand lader dem opgaae

og lader allevegne

Paa deres Agger ligesaa

som paa de Frommes regne. 


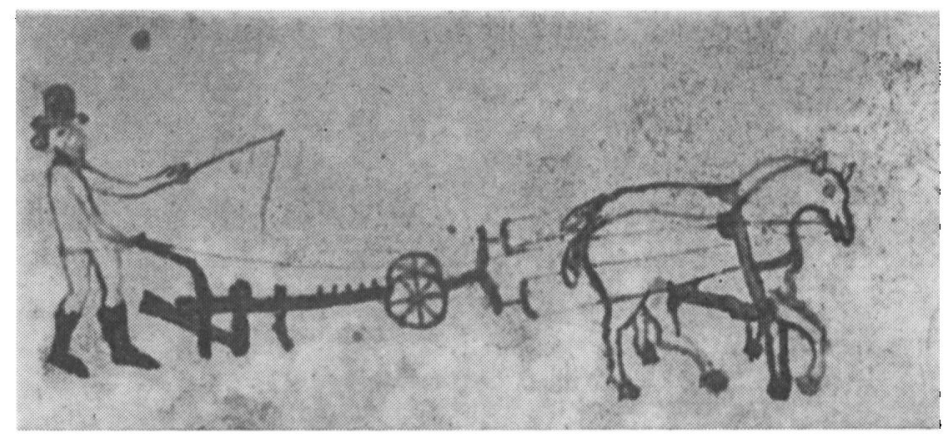

Hjemvendte fra sofarten kom bondesonnerne siden til at gå bag ploven som manden her med den hoje hat og pisken.

Derfor munder salmen ud i en stor tak og lovsang til Gud:

Vi derfor kysser paa din Fod med tusind tak og glæde.

o Gud, vor Gud, hvad est du god, vor Gud paa Arens Sæde.

Disse sidste ord får os til at tænke på en anden og større salmedigter: Brorson. Og der er også flere steder i denne salme efterklange af Brorsons tilsvarende sommersalme: „Op! al den ting, som GUD har giort". ${ }^{25}$ Således i versemål og rytme. Vor salme angives jo også at være skrevet sunder den Mel. Gud Fader udi Himmerig « - netop den samme melodi, som Brorson anviser til sin salme. Men også billeder og udtryk minder os her om biskoppen i Ribe. F. eks. vers 28 :

Mon du din Omhue og din Flid

din Forraad kand tilskrive.

Mon du et Straa vel nogentid

den mindste vext kand give.

De sidste linjer her kalder straks Brorsons vers frem $i$ erindringen:

Gik alle konger frem i rad,

I deres magt og vælde,

De magted' ey det mindste blad

At sette paa en nælde.27

Og versene 30 og 31 :

Vi derfor kysser paa din Fod med tusind tak og glæde.

o Gud, vor Gud, hvad est du god, vor Gud paa Erens Sæde.
O Gud, vor store Gud, vor Gud, hvo kand din Lov udsiunge, hvo kand din ære sige ud med nogen Engel Tunge. 
Også Brorson lader sin salme klinge ud $i$ et betaget udbrud:

Hvad skal jeg sige? mine ord
Vil ikke meget sige;
OGUd! hvad er din viisdom stor,
Din godhed, kraft og rige!
O! priser GUd paa denne jord
Hver, som har sands og tunge,
Og al den deel, i himlen boer,
Vor Skabers lof skal siunge.

Dette er andre ord. Men det er svært at frigøre sig fra den forestilling, at vor salmes digter, da han skulle slutte sin lovprisning af Gud, har haft Brorsons vers $i$ tanke og har lånt klange fra hans instrument - omend resultatet ikke kan måle sig med forbilledet.

Når vi som nævnt vover at se også disse to salmer som stammende fra Hans Mikkelsens pen, kræver dette en begrundelse. At de begge $i$ alt fald er slesvigske, slutter vi af sproget - her forekommer gang på gang udtryk fra slesvigsk bondemål og enkelte slesvigske germanismer. ${ }^{29} \mathrm{Og}$ at de har Hans Mikkelsen til forfatter, slutter vi af indre grunde. F. eks. leverer „Dødens Skue Plads" en skildring af ting, som $i$ alt fald en Kirkens tjener som degnen har haft rig lejlighed til at opleve: Den særlige stemning og luft $\mathrm{i}$ ligstuen — degnen var jo med, når lig blev sunget ud; og de mange ligdele, som kommer for lyset, når en ny grav kastes på en gammel kirkegård - og degnen havde jo som den, der ringede bedeklokken, sin daglige gang over kirkegården. ${ }^{30}$ Denne skildring gør det meget nærliggende at antage $\mathrm{deg}$ nen Hans Mikkelsen som denne salmes forfatter. ${ }^{31}$ Hvad "Overflødighed for Mangel“ angår, synes Hans Mikkelsens forfatterskab endnu sikrere. Thi her forekommer følgende vers:

\footnotetext{
Her maa du nu ret skamfuld staa, du gierig Korne-Puge, som ideligen pønset paa din Næste at opsluge.
}

Og blandt Hans Mikkelsens viser bærer en netop overskriften „Samtale imellem Peder Kornpuge og Jacob Sax, om Forandring i Tiden". ${ }^{32}$ Her skildres den hårdhjertede kornpuger, bonden Peder, der klager over, at alle marker står fulde af afgrøde, hvorved kornpriserne nu synker. Hans omkvæd til denne „dårlige“ tid 
lyder: „Dyrtid ønske vi, det maa Du sikker tro“.93 Thi så får bonden mere for sine varer. $O g$ i tidligere dyrtider „kunde jeg mig længe lade tigge $\mathrm{Og}$ dyrt betale til og have Tak endda".94 Ja, Peder Kornpuge udbryder endog:

Jeg sad med Mængde Korn, men sagde ofte nei.

Jeg svoer vel stundom til, jeg Intet kunde miste,

For det at gjemme op til endnu sværer Tid;

Nu er jeg paa mig selv saa gal, at jeg kan briste.96

Når vi i salmen ikke blot møder en lige så hårdhjertet kornpuger, men også hører følgende anklage imod ham:
Du slog dit Hierte og din Bing saa tit i Laas og Lukke, naar hine efter Korn omkring gik bort og maate sukke.
Hvor tit fornægtet du ey plat, du intet kunne miste, Ja soer dertil vel stundom, at du maate døe og briste.
Endskiønt du havde overflød og nok paa Loft og hilde, Inen prisen blot dig ey anstod, dn meere have vilde -

--- da finder vi både verbalt og indholdsmæssigt en så stor lighed mellem vise og salme, at vi má se den samme mand som forfatler $i$ begge tilfælde - blot med den forskel, at han $i$ visen gør lystigt nar ad kornpugeren, mens han i salmen taler ham til med kristelig alvor og foreholder ham det regnskab, der venter ham hos Gud. Vi vover således at tilkende Hans Mikkelsen forfatterskabet også til "Overflødighed for Mangel“.

Men endnu et spørgsmål må vi her tage stilling til: Er disse to salmer afskrevet i vort hæfte efter nu tabte Luckander-tryk? Vi ved, at Hans Mikkelsen fik adskillige af sine viser trykt hos. Luckander i Haderslev. ${ }^{36}$ Og vi har set, at Hans Jespersens lıæfte rummer afskrifter af $i$ alt fald to Luckander-tryk - nemlig salmen „Brudens Salige Vente“ og Hans Hass' morgen- og aftensalmer. Kan da ikke også de nævnte salmer have nået hans lææfte gennem de små tryk fra Haderslev? Visse ting gør dette meget sandsynligt. Ligesom "Brudens Salige Vente“ har sin egen titelside i hæftet, har også „Dødens Skue Plads“ og „Overflødig- 
hed for Mangel“ det. Har her da ikke først foreligget to tryk, af hvis titelblade vi her ser kopier? Hæftets titelside til „Dødens Skue Plads" er desuden forsynet med en detaljeret pennetegning: Dødsengelen sidder på en kiste flankeret af et timeglas og et slukket, osende lys. Dette motiv har indtil de mindste detaljer så stor lighed med en vignet, som vi gentagne gange finder brugt $i$ Luckanders tryk, ${ }^{37}$ at Hans Jespersen her med sikkerhed kan antages at have haft et Luckander-tryk liggende foran sig, da han udførte sin tegning. Og nederst på titelsiden til „Overflødighed for Mangel" ser vi tegnet en fin krukke med blomster i. Den har så stor lighed med en blomsterkrukke, der er brugt som vignet på $i$ alt fald eet samtidigt Haderslev-tryk, ${ }^{38}$ at vi også her må antage et sådant tryk som forlæg for Hans Jespersens tegning. Vi kan ikke bevise det ved at fremlægge selve de originale tryk. Men det er altså overmåde sandsynligt, at også de to her Hans Mikkelsen tilskrevne salmer har været trykt hos Luckander i Haderslev.

Ja, måske tør vi gå endnu videre og antage det samme om vort hæftes tre sikre Hans Mikkelsen-salmer om Jesu lidelse og død. Thi overskriften over dem er placeret på sin egen side og har derved karakter af et titelblad. Og selve ordvalget og opsætningen her leder også tanken hen på en selvstændig tryktitel:

$$
\begin{gathered}
\text { Herhos et Tillæg } \\
\text { af } \\
\text { nogle faa } \\
\text { Psalmer } \\
\text { sammendigtede } \\
\text { af } \\
\text { Hans Michelsen } \\
\text { med hosføyede } \\
\text { Melodier. }
\end{gathered}
$$

Udtrykket „Herhos et Tillæg“ behøver ikke nødvendigvis at være Hans Jespersens, valgt af ham under den fortskridende afskrivning af hans hæftes indhold. Det kan også dække over det forhold, at de tre følgende salmer har ligget foran ham som del af en salmesamling, som et med eget titelblad udstyret tillæg til et salmetryk, der nu ikke mere er os bekendt. Og har salmerne 


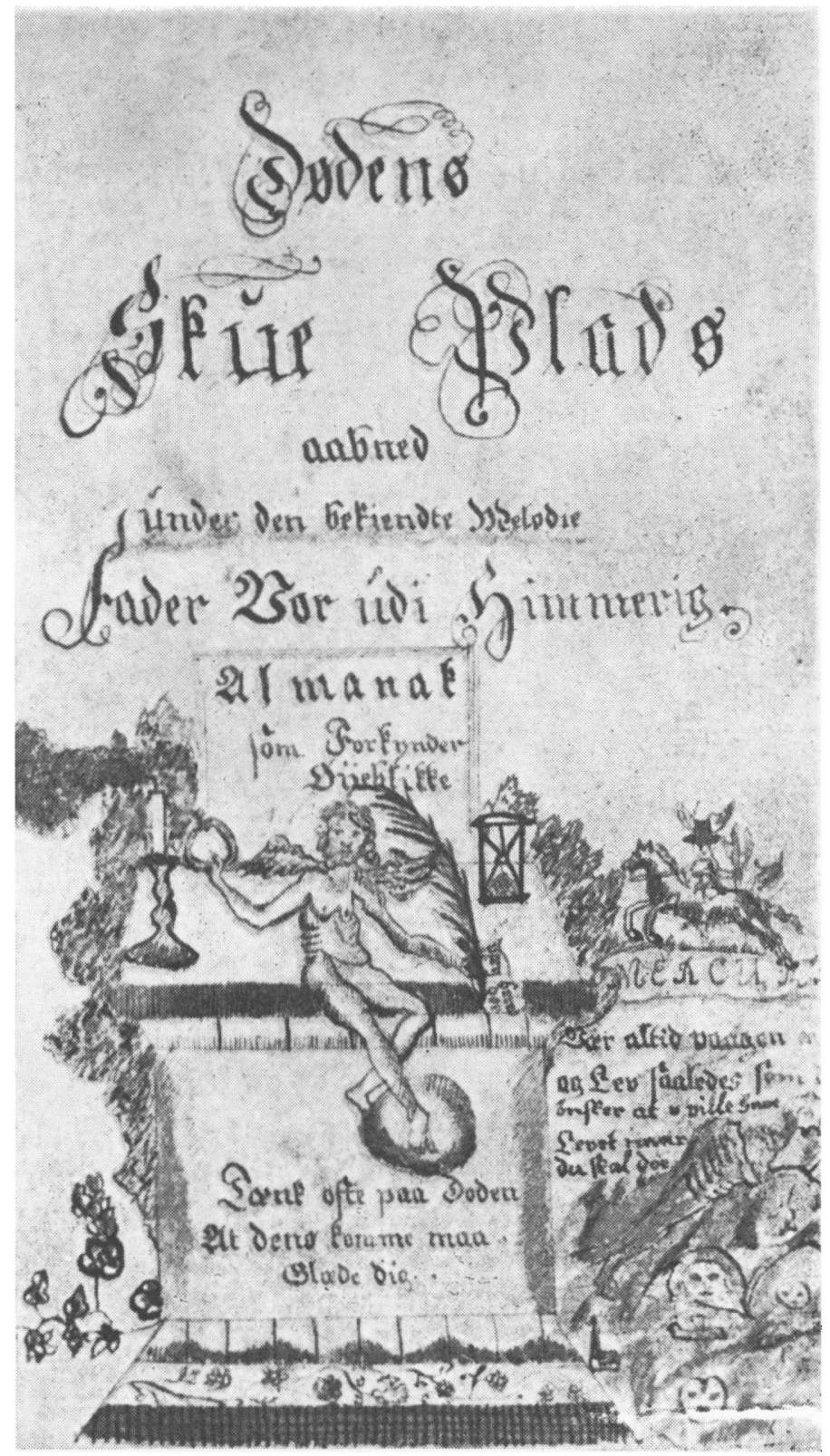

Den händlegnede titelside til haftets salme „Dodens Skue Plads“ viser bl. a. dodsengelen siddende pả en kiste omgivet af det slukte livslys og det udrundne timeglas. Nasten alle detaljerne $i$ denne tegning genfinder vi som vignetter $i$ Luckanders Haderslevtryk. Til hojre lases formaningen: „Var altid vaagen og bered og Lev saaledes som du onsker at ville have Levet naar du skal doe". Og herunder fremhover skelettet og dodningehovederne anbragt midt $i$ landskabet den folgende salmes alvorlige indhold. 
„Dødens Skue Plads“ og „Overflødighed for Mangel“ været tryk! - hvad vi efter det ovenfor fremlagte går ud fra - skulle da ikke også Hans Mikkelsens passionsalmer have været det?

Endeligt må i denne forbindelse nævnes, at vort hæfte rummer endnu to ting, som er omtale værd. Nemlig en hel side, der $i$ en fint tegnet ramme af bladdekoration bærer ordene 》Den Beskiermende Gud " og herunder $i$ et landskab med huse viser en høne, der vogter sine kyllinger. $O g$ en halv side med påskriften "Det Rolige Hierte", hvorunder sees bl. a. en hvilende kvinde. Den antagelse ligger nær, at Hans Jespersen kan have hentet også disse to siders motiver fra titelbladene til nu ukendte tryk, hvis titler har været de anførte ord. Men da disse sider i hans hæf te ikke følges af salmer svarende til deres motiver og påskrifter, melder sig også den mulighed, at vi her står over for kopier efter nogle ikke længere kendte etbladstryk eller efter dele af sådanne. ${ }^{39}$

Skal vi slutteligt sammenfatte, hvad vor beskæftigelse med Hans Jespersens salmehæfte har lært os, da er fundet af Hans Mikkelsens salmer vel det vigtigste resultat — vi har hermed forøget vort kendskab til denne slesvigske digters produktion og tilmed kunnet præstere en rehabilitering af Løjt-degnen: Han var altså ikke kun den sprælske visedigter og synftige brændevinslovpriser, men også en salmedigter af ikke ganske ubetydeligı format. Men også de enkeltheder, hvormed vi har kunnet øge vor viden om Haderslevs ældste bogtrykkeris virke og udbredelsen af dets tryk, er et resultat. Og ikke at forglemme: De i hæftet fundne salmer af endnu ukendt oprindelse, der sammen med dets øvrige indhold kaster nyt lys over slesvigsk kristenliv i det 18. århundredes sidste halvdel. Jo, der er stadigt nok at forske efter og lykkeligvis meget at finde frem i det "skjulte“ Sønderjyllands historie. 


\section{NOTER}

1. Hæftet ejes nu af fru Erika Jespersen i Stollig, enke efter gårdejer Jes Eschelsen Jespersen, som var oldebarn af Hans Hansen Jespersen i Skovby. Jeg skylder fru Erika Jespersen tak for lang tids lån af dette værdifulde arvestykke, ligesom lærer Jes M. Holdt, Rugbjerg, takkes for personalhistoriske oplysninger.

2. Løjt kirkebogs register over konfirmander fra denne tid eksisterer ikke mere. Om pastor Bendixen og vækkelsen $\mathrm{i}$ Løjt sogn se Arends I, s. 40; J. Brodersen: Fra gamle Dage (København 1912), s. 456 ff. og Fr. Schrøder: Brødremenighedens Indre Missions-Gerning i Nordslesvig 1745-1773, i SJy Årb 1939, s. 102.

3. Her som i alle f $\varnothing$ lgende citater er hæftets ortografi bevaret. Kun tegnsætningen er lempeligt ændret og enkelte stavef ejl rettet.

4. Thomas Kingo: Samlede Skrifter III (København 1939), s. 73 ff.

5. Bibliotheca Danica I, sp. 338.

6. »Siælens Himmelsche Jerusalem er behandlet af $H$. Hejselbjerg Paulsen i: Sonderjydsk Psalmesang 1717-1740 (Christiansfeld 1962), s. $71 \mathrm{ff}$. At salmen har været ret kendt, sees deraf, at den i et Luckandertryk fra Haderslev bruges som melodiangivelse. Se Olav Christensen: Haderslev bys forste bogtrykker Hinrich I,uckander 1759-1792 (Haderslev 1959), s. 84, nr. 215.

7. Bindet findes i Universitetsbiblioteket i København.

8. At $>$ Brudens Langselsfulde Kom $\$ 1768$, som mangler angivelse af trykkested, må vare et Luckander-tryk, viser både vignetten på titelbladet og vignetten på s. 2, der begge går igen i flere sikre Luckander-tryk i Christian Knudsens samlebind. Olav Christensens i note 6 nævnte arbejde kan således for året $1768(\mathrm{~s}, 48)$ suppleres med »Brudens Længselsfulde Kom «.

9. Om Hans Hass - 1708-86 - se Bjørn Kornerups uddrag af degnen i Hvirring Herlov Dalhoffs håndskrevne »Lexicolon« $i$ Kirkehist Saml 6. r. II, s. $114 \mathrm{f}$. Dalhoff, der for $\phi$ vrigt er træf ende portrætteret i Sigurd Elkjærs roman $»$ Else Marie«, København 1953, nævner salmerne blandt Hans Hass' få trykte arbejder. Og da han skriver, at han har modtaget en del selvbiografiske oplysninger fra Hass d. 20. oktober 1784, må salmerne være blevet til f $\phi r$ dette år.

10. Trykket, som er på 8 sider i oktav, bærer intet årstal. Se Olav Christensen s. 88, nr. 225. Også andre salmer har Hans Hass fảet trykt $i$ Haderslev: Olav Christensen s. 86, nr. 220 og 221.

11. At også andre jyder end Hans Hass har haft forbindelse med Luckanders trykkeri, fremgår af Herlov Dalhoffs $»$ Lexicolon $\ll$, der nævner, at den næsten blinde bondekarl Peder Pedersen i Hornborg sogn vest for Horsens 1774 fik trykt hos Luckander $\gg$ Tvende gudelige Sange - forfattet af et fattigt Barn i Hornborg-Sogn, Flemming By ved Navn Peder Pedersen\&. Se Kirkehist Saml 6. r. II, s. 132 f. Også her kan således Olav Christensens arbejde om Luckander suppleres med endnu et tryk fra året 1774 (s. 54). Ja, forbindelsen mellem Jylland og Haderslev gik også den modsatte vej, idet samme Peder Pedersen fors $\phi$ rgede sig selv og sine gamle forældre ved at sælge vise- og andre tryk, som han købte i Haderslev. Se Kirkehist Saml 6. r. II, s. 133.

12. Netop i 1890 'erne mærkedes $i$ præsterne P. H. Jensens og C. H. Andresens tid en vis vækkelse i Løjt sogn, skabt af Indre Mission. Se Jes M. Holdt $i$ Den nordslesvigske Kirke II (Haderslev 1948), s. 220. Og det 11897 trykte hæfte indeholder bl. a. to salmer af den til Indre Mission knyttede lægprædikant Jens Sørensen Dyrholm fra Langeland. Om ham se Dansk Biografisk Leksikon VI, s. $158 \mathrm{f}$.

13. Se 》Evangelisk-christelig Psalmebog« nr. 147 og vor nuværende 
salmebog nr. 179. Verset er behandlet af Anders Malling i $\gg$ Dansk Salmehistorie III (København 1963), s. 334 f. Om Ove Malling se Dansk Biografisk Leksikon XV, s. $256 \mathrm{ff}$.

14. Læg mærke til, at også Anders Malling, der på det $\mathrm{i}$ forrige note nævnte sted $i \gg D a n s k$ Salmehistorie $s \not \emptyset g e r$ at bestemme Ove Mallings vers som en fri gendigtning af tanker fra Johann Heermanns tyske salme $\gg$ Jesu, deine tiefe Wunden (Se om denne »Dansk Salmehistorie《 III, s. 10 ff.), bevæger sig forsigtigt på formodningens grund. Måske kan vor her fremsatte hypotese tjene som korrektur til Mallings formodning og anspore til videre forskning over begge versenes tilblivelse. Der er endnu mange huller $i$ vor viden om dansk salmehistorie.

15. H. A. Brorson: Samlede Skrifter II (Kфbenhavn 1953), s. 334 ff.

16. Samme sted s. 336 .

17. At det anf $\emptyset r t e$ gravvers over Hans Mikkelsen er kommet med i Hans Jespersens hæfte, må således tidsfæste dette til et af årene efter 1796. Om Hans Mikkelsen se J. Brodersens i note 2 næevnte arbejde s. 456 og Jes M. Holdt: Skoler og Skolemestre i Løjt Sogn i gamle Dage, i SJy MSkr XII (1935-36), s. 203 ff.; se ogsả ărgang XIV (1937-38), s. 161.

18. Dette omtaler Frederik Fischer i forordet til »Digte af Hans Mikkelsen. Samlede og udgivne af Fr. Fischer «, Aabenraa 1860, s. V.

19. Fr. Fischers i forrige note nævnte udgave af Hans Mikkelsens digtc s. $10 \mathrm{ff} ., 83 \mathrm{ff} ., 113 \mathrm{ff}$. og $173 \mathrm{ff}$.

20. Samme sted s. $30 \mathrm{ff}$. og $167 \mathrm{f}$.

21. Samme sted s. 171 og 182.

22. J. Brodersen s. $456 \mathrm{og}$ Jes M. Holdt i SJy MSkr XII, s. 206 ff. samt J. Hvidtfeldt: Den nordslesvigske Embedsstand 1700-1848, i SJy Årb. 1958 , s. $188 \mathrm{f}$.

23. Fr. Fischers udgave s. 184.

24. Sammenlign $\mathrm{f}$. eks. hans selvanklage: J e g var skyld i din lidelse og død, med Paul Gerhardts salme $\gg \mathrm{O}$ Haupt! voll Blut und Wunden (»Dansk Salmehistorie« IV (København 1964), s. 143 f.), der bygger på middelalderdigteren, abbed Arnulf af Louvain, og med Kingos vers :

\author{
Jo, min Gud, Jeg bør ey dolge, \\ At min synd foruden Tal \\ Jo vaar med Dig hen at folge \\ Ind i Dommens Huus og Sal! \\ Mine synder Dommen skrev, \\ Og Dig hen til Døden rev! \\ Hvor Jeg seer din Dom og Vunder. \\ Seer Jeg alt mit Segl der under.
}

(Samlede Skrifter IV (Kфbenhavn 1941), s. 426).

25. Samlede Skrifter I (København 1951), s. 217 ff.

26. Samme sted s. 217 .

27. Samme sted s. 218 .

28. Samme sted s. 219 .

29. Se f. eks. $\gg$ D $\varnothing$ dens Skue Plads $«$, v. 2: $\gg$ At du her ingen $\mathrm{H}$ i e m m e har\& og v. 13: »Den matte Puls i e meer og meer Aftager\&. Og $\gg$ Overflødighed for Mangel«, v. 13: $\gg$ F $\phi r$ s in e [d. v.s. Guds] Børn skal lide Nød, Maa vand af Klipper springe« og v. 24: flød og nok på Loft og h ild e«.

30. Endnu i 1862 nævner det da trykte $\gg$ Kirkeinventarium for Løjt Sogn « s. $13 \mathrm{f}$. degnens tjeneste med bedeklokken og omtaler ham endog som både klokker og graver og opsynsmand over kirkegården. 
31. Endnu to indicier i samme retning må næunes: På salmens titelblad i vort hæfte er bl. a. tegnet en rytter på en galloperende hest; og under ham star navnet »MERCURIUS «. Dette får os straks til at tænke pá Hans Mikkelsens vise »Extract af Udkast og Concepter, som Diogenes - - haver opmærket«, hvis sidste vers nævner samme person, også her i hastig galop:

Det Øvrige jeg alt fra mig i Reent leverte

Of af Mercurius en Skriverlon begjærte,

Som mig paa Timen min Begjæring plat afslog

Og $\sin$ Nærværelse paa $\emptyset j \mathrm{jeblik}$ unddrog.

(Fr. Fischers udgave s. 57).

Endvidere bærer salmens titelblad udtrykket »under den bekiendte Melodie«. Nøjagtigt samme udtryk forekommer i titelen til en anden af Hans Mikkelsens viser, »Extract af en heel Søndag-Eftermiddags Landsby-Prædiken«. Se Fr. Fischers udgave s. 143.

32. Samme sted s. $93 \mathrm{ff}$.

33. Samme sted s. 97.

34. Samme sted s. 95 .

35. Samme sted s. 96 .

36. Samme sted s. V og 167. Olav Christensen nævner også - s. 44, nr. 44 - et mere seriøst, nu tabt digt af Hans Mikkelsen i anledning af kong Frederik V's død trykt af Inckander 1766. Og forfatteren selv har på Kegnæs fundet et fragment af Løjt-degnens i note 31 næunte $\gg$ Extract af en heel Søndag-Eftermiddags Landsby-Prædiken«. Fragmentet svarer til siderne 144-51 i Fr. Fischers udgave. Denne vise er for $\emptyset v r i g t$ det eneste af hele Hans Mikkelsens produktion, for hvilket han nxvnes i Ehrencron-Müllers danske forfatterleksikon - se bind V, s. 392. Det er således ikke ubegrundet at gøre opmærksom pi denne digter, at han ikke skal glemmes helt iblandt os!

37. Se »En meget smuk Nye Sang, over det menneskelige Livs Løb - - Trykt i Haderslev $1789_{«}$ og $\gg$ Fire aandelige Sange - - Haderslev, trykt og at bekomme hos H. Luckander», uden år, der begge anf $\emptyset \mathrm{res}$ hos Olav Christensen s. 72, nr. 160 og s. 80 f., nr. 199. Endvidere $\gg$ En Christens Testamente, eller Forberedelse til Døden - - - Haderslev, trykt og at bekomme i dette Steds Bogtrykkerie«, uden år. Dette sidste tryk er ikke næunt hos Olav Christensen, men findes i Christian Knudsens samlebind »Gudelige Viser og Psalmer trykt i Haderslev《 som nr. 41, hvor også førstnævnte tryk 1789 findes som nr. 13. Nævnes skal også den lille slutvignet i »'Trende Gudelige Viser. Den F $\phi r$ ste: Om Langsel efter Døden - - - Haderslev, at bekomme i Bogtrykkeriet«, uden år (Christian Knudsens samlebind nr. 45) : En engel sees med en palmegren og en ring eller máske snarere en krans $i$ hænderne. Dødsengelen i vort hæfte bærer i sine hænder nøjagtigt de samme ting.

38. Etbladstrykket »Et glædeligt Nyt-Aars Ønske til en Huus-Fader - - [og] en Huus-Moder af den haderlige Bonde-Stand «. Dette tryk, som er uden år, må stamme fra tiden omkring 1800, men har antageligt haft nu tabte forgængere. Beskrivelse af det samt formindsket gengivelse af vignetten findes hos V. E. Clausen: Det folkelige danske træsnit i etbladstryk 1650-1870 (København 1961), s. 127, nr. 195 og Johs. Chr. Nielsen: 165 Aar. Et nordslesvigsk Bogbinder- og Boghandlerfirma fra 1765-1930 (Haderslev 1931), s. 24.

39. Om denne litteraturgren - også som den dyrkedes i Sønderjylland se V. E. Clausens i forrige note navnte arbejde. 